\title{
Insulin-Like Growth Factor (IGF)-I and IGF-Binding Protein 3 during the First Year in Term and Preterm Infants
}

\author{
SUJATHA RAJARAM, SUSAN E. CARLSON, WINSTON W. K. KOO, ANU RANGACHARI, AND \\ DAVID P. KELLY \\ Departments of Pediatrics [S.R., S.E.C., W.W.K.K.] and Obstetrics and Gynecology [S.R., S.E.C., \\ W.W.K.K.], The University of Tennessee, Memphis, Memphis, Tenessee 38163 and Endocrine Sciences, \\ Calabasas Hills, California [A.R., D.P.K.]
}

\begin{abstract}
Plasma IGF-I and IGF-binding protein $3($ IGFBP-3) were
determined by radioimmunoassay in term infants $(n=51)$ at 0 , $2,4,6$, and $12 \mathrm{mo}$ and preterm infants $(n=51)$ at $-3(28.4 \mathrm{wk}$ postconceptional age), $-2,-1.5,-1,0,2,4,6,9$, and $12 \mathrm{mo}$ from expected term. The effects of gestational age at birth (term or preterm) and study age were determined by repeated measures analysis of variance and Fisher's least squares difference. In preterm infants, IGF-I increased between -3 and 2 mo from 0.75 to $10.4 \mathrm{nM}$, decreased between 2 and 9 mo to $7.3 \mathrm{nM}$, and increased again between 9 and 12 mo to $10.1 \mathrm{nM}(p<0.0001)$, whereas IGFBP-3 increased relatively little from -3 to 0 mo (14.2 to $30.2 \mathrm{nM}, p<0.05)$ and plateaued from 2 to $12 \mathrm{mo}(49.8$ to $62.3 \mathrm{nM}$ ). At $0 \mathrm{mo}$, IGF-I and IGFBP-3 were the same in term and preterm infants, but preterm infants had higher IGF-I from 2
\end{abstract}

through $12 \mathrm{mo}(p<0.05)$, higher IGFBP-3 at 2 and $4 \mathrm{mo}(p<$ $0.05)$, and lower IGFBP-3 at 12 mo $(p<0.05)$. IGF-I and IGFBP-3 were correlated at most ages. First year IGF-I and IGFBP-3 are influenced by study age and by gestational age, even after adjusting for early birth. (Pediatr Res 37: 581-585, 1995)
IGFBP, IGF-binding protein
ANOVA, analysis of variance
LSD, least squares difference
PCA, postconceptional age
RIA, radioimmunoassay

IGF mediate the growth-promoting actions of growth hormone in regulating the proliferation and differentiation of different cell types (1). These polypeptides which are structurally homologous to insulin also exert insulin-like metabolic effects. Both these effects are mediated through target cell surface receptors (2). Most tissues in the body produce IGF, and they are present in serum mostly bound to specific high molecular weight binding proteins (3). Of the six IGFBP that have been identified so far, IGFBP-3 is the major form present in the serum $(1,2)$ and demonstrates a high affinity for both IGF-I and IGF-II. IGFBP-3 can exhibit either an inhibitory (4) or a potentiating (5) effect on IGF-I bioactivity in vitro, depending on its ability to alter the equilibrium between IGF-I and its receptor (5).

Received September 8, 1994; accepted December 10, 1994.

Correspondence: Dr. Susan E. Carlson, Newborn Center, Room 201, 853 Jefferson Avenue, Memphis, TN 38163.

Supported by grants from National Institutes of Health (R01 EY08770, R01 HD31329) and a gift from Ross Products Division, Abbott Laboratories, Columbus, $\mathrm{OH}$.

A preliminary form of these data was presented at the 1994 annual meeting of the Society for Pediatric Research.
Although IGF-I is thought to play an important role in postnatal growth $(6-15)$, there is disagreement among authors (16-19) about the effects of postnatal age on plasma IGF-I in early infancy. The usefulness of obtaining plasma IGF-I concentrations in infancy is limited because normal values for this age group have not been established. Data on the circulating IGF-I concentrations in healthy term infants in early infancy are available from only five published reports (10, 16-19). These studies were either cross-sectional $(10,16,17)$ or followed a relatively small number of infants longitudinally (1619). Plasma IGFBP-3 concentration during infancy has not been reported previously. The objectives of this study were to establish normative data on plasma IGF-I and IGFBP-3 throughout infancy in healthy infants born at term and to contrast these concentrations to those of appropriate-forgestational-age preterm infants selected from the same population.

\section{METHODS}

Subject enrollment. Healthy term infants were enrolled at birth and were followed at approximately bimonthly intervals 
Table 1. Neonatal and perinatal characteristics of the study infants

\begin{tabular}{lcc}
\hline \multicolumn{1}{c}{ Variable } & Term $(n=51)$ & Preterm $(n=51)$ \\
\hline Birth weight $(\mathrm{g})$ & $3317 \pm 388(2600-4095) *$ & $1023 \pm 152(747-1274)$ \\
Gestational age (wk) & $40.0 \pm 1.0(38-42)$ & $27.8 \pm 1.4(24-30)$ \\
Black/White & $41: 10$ & $44: 7$ \\
Male/Female & $25: 26$ & $23: 28$ \\
Apgar at 5 min & $9.0 \pm 0.3(8-10)$ & $7.2 \pm 1.3(4-10)$ \\
Maternal age (y) & $22 \pm 4(17-33)$ & $23 \pm 6(16-38)$ \\
Maternal height (cm) & $163.4 \pm 6.4(150-180)$ & $163.3 \pm 5.7(151-178)$ \\
Gravida & $1.8 \pm 0.8(1-4)$ & $2.5 \pm 1.2(1-5)$ \\
\hline
\end{tabular}

$* \mathrm{X} \pm \mathrm{SD}$ (range).

from birth until 12 mo of age. Apropriate-for-gestational-age preterm infants $(28.4 \pm 1.5$-wk PCA, mean \pm SD) were enrolled after birth or -3 mo from expected term and followed longitudinally until $12 \mathrm{mo}$ (this and all subsequent ages were corrected to expected term). Parental consent was obtained before enrollment according to a protocol approved by the Institutional Review Board of The University of Tennessee, Memphis. Both the term and the preterm infants were selected from the same hospital population. The neonatal and perinatal characteristics of the study infants are given in Table 1.

Study design. Term and preterm infants were the subjects of separate but concurrent randomized trials to study the effects of long chain N-3 or N-6 fatty acids on development. Term infants received either human milk or a term formula (Similac with Iron, Ross Products Division, Abbott Laboratories, Columbus, $\mathrm{OH}$ ) ad libitum from birth until $12 \mathrm{mo}$. Preterm infants received their required nutrients parenterally starting at $24-72$ $\mathrm{h}$ of age and were started on a preterm formula (Similac Special Care, Ross Products Division, Abbott Laboratories) at a mean of $3.75 \mathrm{~d}$ of age. From -2 to 2 mo, preterm infants received Similac Special Care as their only feeding. After 2 mo, they were provided with term formula (Similac with Iron) until 12 mo.

Blood sampling. Blood was collected from term infants at birth ( 0 mo, $40 \pm 1$ wk PCA), 2 mo ( $48 \pm 1$ wk PCA), 4 mo (57 $\pm 1 \mathrm{wk}$ PCA), $6 \mathrm{mo}(66 \pm 1 \mathrm{wk} P C A)$, and $12 \mathrm{mo}$ (92 \pm 1 wk PCA). Blood was collected from preterm infants near birth, when they reached an enteral intake of $\geq 100 \mathrm{kcal} / \mathrm{kg} / \mathrm{d}$, and at biweekly intervals thereafter until discharge from the hospital: -3 mo (3-5 d of age, $28 \pm 2$ wk PCA), -2 mo (32 $\pm 2 \mathrm{wk} P C A),-1.5 \mathrm{mo}(34 \pm 2 \mathrm{wk} P C A)$, and $-1 \mathrm{mo}$ (36 \pm 2 wk PCA). After hospital discharge, samples were obtained at 0 mo ( $39 \pm 1$ wk PCA), 2 mo ( $48 \pm 1$ wk PCA), 4 mo (57 \pm 1 wk PCA), 6 mo ( $69 \pm 1$ wk PCA), 9 mo (79 \pm 1 wk PCA), and $12 \mathrm{mo}$ (92 \pm 1 wk PCA). Blood was centrifuged, and plasma was separated and stored in a nitrogen atmosphere at $-70^{\circ} \mathrm{C}$ until analyzed for IGF-I and IGFBP-3.

Analytical methods. Plasma IGF-I and IGFBP-3 were determined by RIA (Endocrine Sciences, Calabasas Hills, CA). Most samples were diluted 1:151. Low value samples may have been repeated on an even lesser dilution. The IGF-I RIA (20) used a specific, high-affinity polyclonal antibody for IGF-I that does not cross-react with IGF-II $(<0.05 \%)(21)$. IGF-I RIA uses recombinant human IGF-I for tracer (prepared through radioiodination) and standards. The standards are calibrated with recombinant human IGF-I devoid of methionine
IGF-I variants with mismatched disulfide bonds; i.e. identical to the major authentic IGF-I form in blood. (The IGF-I concentration in a serum pool from normal adults was $180 \mu \mathrm{g} / \mathrm{L}$ or $23.1 \mathrm{nM}$ compared with $220 \mu \mathrm{g} / \mathrm{L}$ or $28.3 \mathrm{nM}$ obtained before the availability of high-affinity polyclonal antibody.) The lowest level of detection for the assay is $2 \mathrm{pg} /$ tube. Half-maximal displacement $\left(\mathrm{B} / \mathrm{B}_{0}=0.50\right)[\mathrm{B}=$ total sample binding $(\mathrm{cpm})$ - nonspecific binding (cpm)/total counts added; $\mathrm{B}_{0}=$ total cpm bound at 0 dose - nonspecific binding (cpm)/total counts added.] occurs at $110 \mathrm{pg} /$ tube $(0.14 \mathrm{nM})$. IGF-I RIA is free from interference by IGFBP because the IGF-binding site is occupied by IGF-II. After IGF are dissociated from IGFBP by acidification, the IGF-binding sites are then occupied by excess IGF-II added in neutralizing buffer. The interassay and intraassay coefficients of variation at $50 \% \mathrm{~B} / \mathrm{B}_{0}$ were $7.4 \%$ and $3.2 \%$ $(n=20)$, respectively.

The IGFBP-3 RIA (22) does not react with IGFBP-1 or -2 or IGF-I or -II. The lowest level of detection of the assay is 40 $\mathrm{pg} /$ tube with a $\mathrm{B} / \mathrm{B}_{0}=0.50$ of $600 \mathrm{pg} /$ tube. The interassay and intraassay coefficients of variation were 5.5 and $5.1 \%$, respectively, at $\mathrm{B} / \mathrm{B}_{0}=0.50$.

Statistical analyses. Data were analyzed by the general linear model procedure of SAS version 6.0 (Cary, NC). Each preterm infant had at least five measurements from 10 sampling ages, and term infants had at least three measurements from five sampling ages. Diet (human milk or formula) was used as a potentially influential variable in the preliminary statistical design but was removed when effects of diet were not found. The effect of gestational age at birth and time (study age) on IGF-I and IGFBP-3 was determined by a two-way repeated measures ANOVA corrected for the effect of subject by using the subject-simultaneous sums of squares as an error term. By correcting for the effect of subject, the influence of possible covariants is eliminated from the analysis. The ages included were $0,2,4,6$, and 12 mo when data from both term and preterm infants were available. Because blood was available at an additional number of ages in preterm compared with term infants, a repeated measures ANOVA corrected for subject effects was also performed for each gestational age group to determine the effect of study age or study age and gender on plasma IGF-I and IGFBP-3 concentrations. Fisher's LSD was used for comparisons within (study age, gender) and between (gestational age at birth) groups. Pearson's correlation was used to determine the relationship between IGF-I and IGFBP-3 at all ages. A $p$ value $<0.05$ was considered significant in all analyses. All analyses were completed by using software from SAS Institute, Inc. (23). on the mainframe computer at The University of Tennessee, Memphis.

\section{RESULTS}

In term infants, there was no overall effect of study age on first year plasma IGF-I, although the plasma IGF-I concentration declined progressively from $7.6 \pm 0.6 \mathrm{nM}(59.1 \pm 4.3$ $\mu \mathrm{g} / \mathrm{L})($ mean $\pm \mathrm{SE})$ at birth to $5.3 \pm 0.4 \mathrm{nM}(41.4 \pm 3.3 \mu \mathrm{g} / \mathrm{L})$ at $6 \mathrm{mo}$ and increased again to $7.2 \pm 0.6 \mathrm{nM}(55.8 \pm 4.7 \mu \mathrm{g} / \mathrm{L})$ by $12 \mathrm{mo}$ of age (Table 2). By Fisher's LSD comparison, the IGF-I concentration at 6 mo was significantly lower than at 
Table 2. Plasma IGF-I concentration in term and preterm infants in infancy

\begin{tabular}{ccccc}
\hline Age (mo) & $n$ & Term (nM) & $n$ & Preterm* $(\mathrm{nM})^{*}$ \\
\hline 0 & 35 & $7.6 \pm 0.6(2-14)^{\mathrm{a}}$ & 49 & $6.5 \pm 0.4(3-12)^{\mathrm{a}}$ \\
2 & 45 & $7.1 \pm 0.4(2-14)^{\mathrm{a}}$ & 45 & $10.4 \pm 0.4(3-21)^{\mathrm{b}} \dagger$ \\
4 & 44 & $6.4 \pm 0.4(1-16)^{\mathrm{ab}}$ & 27 & $9.5 \pm 0.6(3-22)^{\mathrm{b}} \dagger$ \\
6 & 48 & $5.3 \pm 0.4(1-12)^{\mathrm{b}}$ & 24 & $7.8 \pm 0.6(2-17)^{\mathrm{a}} \dagger$ \\
12 & 27 & $7.2 \pm 0.6(2-13)^{\mathrm{ab}}$ & 29 & $9.9 \pm 0.6(2-23)^{\mathrm{b}} \dagger$ \\
\hline
\end{tabular}

Data shown are least squares means \pm SE from two-way ANOVA for the effects of gestational age at birth and study age in each group. Ranges are given in parentheses. To determine IGF-I in $\mu \mathrm{g} / \mathrm{L}$, multiply IGF-I (nM) by 7.78 .

* Values from preterm infants were determined at these ages from expected term gestation. The complete developmental change in IGF-I after preterm birth is illustrated in Figure 1. Within each group, ages with different letters as superscript are significantly different from one another $(p<0.05)$.

$\dagger$ Significant differences between term and preterm infants at the same study age $(p<0.05)$.

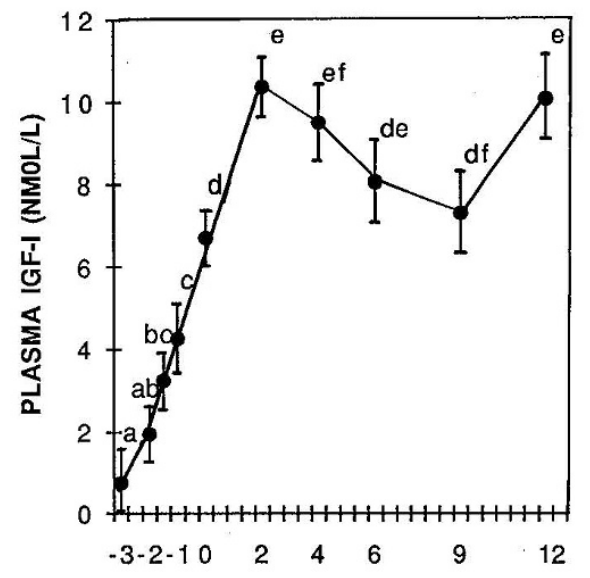

AGE (MO FROM TERM)

Figure 1. Least squares means of plasma IGF-I concentration $( \pm \mathrm{SE})$ in preterm infants $(n=51)$ during the first year of life from one-way repeated measures ANOVA: $-3 \mathrm{mo}(n=31),-2 \mathrm{mo}(n=46),-1.5 \mathrm{mo}(n=47),-1$ mo $(n=34), 0$ mo $(n=49), 2$ mo $(n=45), 4$ mo $(n=27), 6$ mo $(n=24)$, $9 \mathrm{mo}(n=25)$, and $12 \mathrm{mo}(n=29)$. Ages with different letter designations are significantly different by Fisher's LSD test $(p<0.05)$.

birth $(p<0.03)$ and 2 mo $(p<0.05)$ of age (Table 2). In contrast, there was a significant effect of study age on plasma IGF-I concentration in preterm infants (ANOVA, $p<0.0001$ ).

In the preterm infants, plasma IGF-I was very low $(0.75 \pm$ $0.85 \mathrm{nM}$ or $5.8 \pm 6.6 \mu \mathrm{g} / \mathrm{L})$ at enrollment $(-3 \mathrm{mo})$ and increased significantly until 2 mo corrected age $(p<0.0001)$ (Fig. 1) when plasma IGF-I concentration was $10.4 \pm 0.7 \mathrm{nM}$ or $80.8 \pm 5.4 \mu \mathrm{g} / \mathrm{L}$. The IGF-I concentration declined significantly between 2 and 9 mo $(p<0.01)$, then between 9 and 12 mo increased back to the high concentration seen at 2 and 4 mo (Fig. 1, Table 2).

There was a significant interaction between gestational age at birth and study age for IGF-I plasma concentration $(p<$ 0.0001 ). As noted above, between 0 and 2 mo, IGF-I increased in preterm but not term infants. Preterm infants had a higher circulating IGF-I concentration than term infants at 2, 4, 6, and 12 mo corrected age (Table 2; $p<0.02$ ).

There was a significant effect of study age on IGFBP-3 in both term and preterm infants (ANOVA, $p<0.0001$ ). In term

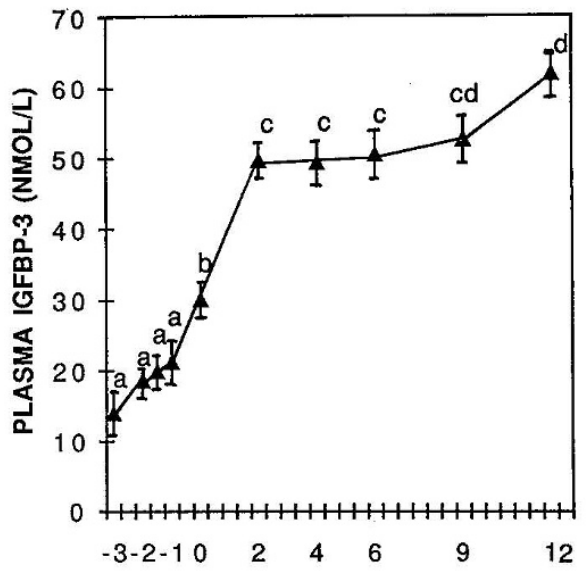

AGE (MO FROM TERM)

Figure 2. Least squares means of plasma IGFBP-3 concentration $( \pm S E)$ in preterm infants $(n=51)$ during the first year of life from one-way repeated measures ANOVA: $-3 \mathrm{mo}(n=31),-2 \mathrm{mo}(n=46),-1.5 \mathrm{mo}(n=47),-1$ mo $(n=34), 0 \mathrm{mo}(n=49), 2 \mathrm{mo}(n=45), 4 \mathrm{mo}(n=27), 6 \mathrm{mo}(n=24)$, 9 mo $(n=25), 12$ mo $(n=29)$. Ages with different letter designations are significantly different by Fisher's LSD test $(p<0.05)$.

infants, there was a significant increase in IGFBP-3 from 29.2 \pm 1.6 to $42.0 \pm 1.3 \mathrm{nM}(0.89 \pm 0.05$ to $1.28 \pm 0.04 \mathrm{mg} / \mathrm{L})$ between 0 and $2 \mathrm{mo}(p<0.01)$ followed by a plateau between 2 and 6 mo. From 6 to $12 \mathrm{mo}$, IGFBP-3 increased again to 70.2 $\mathrm{nM}(2.14 \mathrm{mg} / \mathrm{L})(p<0.0001)$. The significant increase in plasma IGFBP-3 after term birth was in contrast to the significant decrease in plasma IGF-I concentration during the same period. In preterm infants, the mean plasma IGFBP-3 concentration at enrollment $(-3 \mathrm{mo})$ was $14.1 \pm 3.0 \mathrm{nM}(0.43 \pm 0.09$ $\mathrm{mg} / \mathrm{L}$ ). The concentration increased throughout the expected last intrauterine trimester and reached $29.8 \pm 1.3 \mathrm{nM}(0.91 \pm$ $0.04 \mathrm{mg} / \mathrm{L}$ ) at expected term (Fig. 2). There was another increase in IGFBP-3 concentration between 0 and 2 mo $(p<$ 0.0001 ) after which IGFBP-3 plateaued from 2 through 6 mo, then increased again between 6 and $12 \mathrm{mo}(p<0.003)$ (Fig. 2, Table 3$)$. IGFBP-3 was significantly higher in preterm infants compared with term infants $(p<0.05)$ at 2 and 4 mo and significantly lower at $12 \mathrm{mo}$ (Table 3 ).

Table 3. Plasma IGFBP-3 concentration in term and preterm infants in infancy

\begin{tabular}{ccccc}
\hline Age (mo) & $n$ & Term (nM) & $n$ & Preterm* $(\mathrm{nM})^{\mathrm{a}}$ \\
\hline 0 & 35 & $29.2 \pm 1.6(14-56)^{\mathrm{a}}$ & 49 & $29.8 \pm 1.3(10-46)^{\mathrm{a}}$ \\
2 & 45 & $42.0 \pm 1.3(16-69)^{\mathrm{b}}$ & 45 & $51.1 \pm 1.6(30-75)^{\mathrm{b}} \dagger$ \\
4 & 44 & $45.6 \pm 1.6(20-79)^{\mathrm{b}}$ & 27 & $50.5 \pm 2.0(13-72)^{\mathrm{b}} \dagger$ \\
6 & 48 & $47.5 \pm 1.3(16-79)^{\mathrm{b}}$ & 24 & $50.8 \pm 2.0(33-75)^{\mathrm{b}}$ \\
12 & 27 & $70.2 \pm 2.0(26-98)^{\mathrm{c}}$ & 29 & $60.3 \pm 2.0(33-92)^{\mathrm{c}} \dagger$ \\
\hline
\end{tabular}

Data shown are the least squares means $\pm \mathrm{SE}$ from two-way ANOVA for the effects of gestational age at birth and study age in each group. Ranges are given in parentheses. To determine IGFBP- 3 in $\mathrm{mg} / \mathrm{L}$, multiply IGFBP-3 in $\mathrm{nM}$ by 0.0305 .

* Values from preterm infants were determined at these ages from expected term gestation. The complete developmental change in IGFBP-3 after preterm birth is illustrated in Fig. 2. Within each group, ages with different letters as superscript are significantly different from one another $(p<0.05)$.

$\dagger$ Denotes a significant difference between term and preterm infants of the same age $(p<0.05)$. 
Table 4. Correlation of individual concentrations of plasma IGF-I and IGFBP-3 in term infants in infancy

\begin{tabular}{ccc}
\hline Age $(\mathrm{mo})$ & Correlation $(r)$ & $p$ \\
\hline 0 & 0.50 & $<0.004$ \\
2 & 0.75 & $<0.0001$ \\
4 & 0.78 & $<0.0001$ \\
6 & 0.57 & $<0.001$ \\
12 & 0.68 & $<0.0001$ \\
\hline
\end{tabular}

Table 5. Correlation of individual concentrations of plasma IGF- $I$ and IGFBP-3 in preterm infants from birth to 1 y past expected term

\begin{tabular}{ccc}
\hline Age (mo) & Correlation $(r)$ & $p$ \\
\hline-3 & 0.38 & $<0.04$ \\
-2 & 0.53 & $<0.001$ \\
-1.5 & 0.20 & NS \\
-1 & 0.40 & NS \\
0 & 0.35 & $<0.012$ \\
2 & 0.59 & $<0.0001$ \\
4 & 0.62 & $<0.007$ \\
6 & 0.61 & $<0.004$ \\
9 & 0.67 & $<0.0002$ \\
12 & 0.52 & $<0.009$ \\
\hline
\end{tabular}

When study age and gender were included in the ANOVA for each group, males born at term had lower plasma IGFBP-3 concentrations than females $(p<0.03)$ at 0 mo $(23.0$ versus $32.8 \mathrm{nM}$ or $0.7 \mathrm{mg} / \mathrm{L}$ versus $1.0 \mathrm{mg} / \mathrm{L})$ of age and $6 \mathrm{mo}(39.3$ versus $47.5 \mathrm{nM}$ or $1.2 \mathrm{mg} / \mathrm{L}$ versus $1.55 \mathrm{mg} / \mathrm{L}$ ). Similarly, in the preterm group, males had lower IGFBP-3 concentration than females at 6 mo of age ( 45.2 versus $54.2 \mathrm{nM}$ or 1.38 versus $1.65 \mathrm{mg} / \mathrm{L}, p<0.05$ ). Gender did not influence plasma IGF-I in term or preterm infants at any age.

Plasma IGF-I and IGFBP-3 concentrations in individual infants were significantly correlated at every age for both term (Table 4) and preterm (Table 5) infants except at -1.5 mo and $-1 \mathrm{mo}$ in the preterm group.

\section{DISCUSSION}

IGF-I is thought to play an important role in postnatal growth. Plasma IGF-I is elevated in patients with acromegaly $(6,7)$ and in constitutionally tall children and adolescents $(8)$ and is lower in pygmies (9), individuals with Laron-type dwarfism (10), intrauterine growth-retarded fetuses (11), and children with constitutionally delayed growth $(12,13)$. Declines in growth rate among children with protein energy malnutrition (14) are accompanied by lower plasma IGF-I levels, whereas subsequent refeeding reverses protein energy malnutrition, increases plasma IGF-I levels, and restores normal growth (15).

Several groups of investigators $(12,17,24,25)$, employing either bioassays or RIA, have shown that at term birth the cord somatomedin C IGF-I concentration is lower than normal adult values $(>25.7 \mathrm{nM}$ or $200 \mu \mathrm{g} / \mathrm{L})$. Our finding of a lower than normal adult ( $>26 \mathrm{nM}$ or $200 \mu \mathrm{g} / \mathrm{L}$ ) concentration of IGF-I in cord blood of term infants $(73.9 \mu \mathrm{g} / \mathrm{L})$ is consistent with these reports. There is disagreement, however, about the effects of postnatal age on plasma IGF-I in infancy. Tato et al. (16) and
Kaplowitz et al. (17) measured plasma IGF-I/somatomedin C activity in a cross-section of infants. The first group found higher values in the first week of life compared with later (23 $\mathrm{d}$ to $15 \mathrm{mo}$ ), whereas the second group reported concentrations in cord blood to be similar (males) or lower (females) compared with concentrations during the next 15 mo of life. Kaplowitz et al. (17) also measured first year somatomedin C in longitudinal samples and found little effect of age. Two longitudinal studies with smaller numbers of infants found either no change in circulating IGF-I between birth and 3 mo (19) or a prominent early postnatal increase followed by a decrease between 2 and $6 \mathrm{wk}$ of age (18). The data presented here represent a relatively large number of term infants $(n=$ 51) followed longitudinally during the first year of life. Our data show a progressive decline in IGF-I concentration between birth and 6 mo that reaches significance but no overall effect of time on the first-year IGF-I concentration.

The pattern of IGF-I development from childhood to adult life has been more consistently established $(8,12,26)$. Although the methodologies are still evolving, the plasma IGF-I concentration typically increases with age in young children $(>10.3 \mathrm{nM}$ or $80 \mu \mathrm{g} / \mathrm{L})$ with a prominent surge $(>51 \mathrm{nM}$ or $400 \mu \mathrm{g} / \mathrm{L})$ at puberty $(20,27)$. Thereafter, plasma IGF-I declines steadily until normal adult values are reached $(12,25)$. After $40 \mathrm{y}$ of age, IGF-I declines again to levels lower than in early adulthood (26).

In humans, IGF-I/somatomedin C synthesis begins as early as 9-19 wk of gestation (28). Lassarre et al. (25) showed an increase in blood IGF-I during the last intrauterine trimester in a cross-sectional study of umbilical cord samples obtained during the 20th to the 37th wk of gestation. The gradual increase in IGF-I during the interval corresponding to the last intrauterine trimester shown in our study is consistent with the above report (25) but cannot be used to infer that third trimester intrauterine and extrauterine IGF-I are the same.

There are two other longitudinal reports of circulating levels of IGF-I in preterm infants, each of relatively short duration $(18,29)$. One (29) reported a decline in plasma IGF-I levels in nine sick, parenterally fed preterm infants between 6 and $28 \mathrm{~d}$ of age. The other (18) showed a trend for circulating levels of IGF-I to increase between birth and 6-wk adjusted age in infants born between 26 and 37 wk PCA ( -3.5 and $-1.5 \mathrm{mo})$. The population included infants who were appropriately grown as well as small for gestational age. The evidence thus favors a developmental increase in IGF-I expression during the last intrauterine trimester as we show here. However, although IGF-I decreased after birth in term infants, IGF-I in preterm infants increased between term and 2 mo and was remarkably higher in preterm compared with term infants at the four ages when samples from both gestational age groups were obtained: 2, 4, 6, and 12 mo (Table 2).

The bioavailability of circulating IGF-I to target tissues is influenced by the associated binding protein(s). IGFBP-1 and IGFBP-2 are strongly expressed in the fetus (25) and are predominant in premature neonates of gestational ages 28-34 wk. The cord blood at term birth contains more IGFBP-3 (24), suggesting that there is a transition in the expression of binding proteins from fetal to postnatal life. The longitudinal data 
presented here are consistent with these observations in that they show an increase in IGFBP-3 during the interval corresponding to the last intrauterine trimester and much higher concentrations after expected term. Again, as noted for IGF-I, these data cannot be construed to mean that the third trimester intrauterine and extrauterine IGFBP-3 concentrations are the same.

Among infants studied at a given age, there was a highly significant positive relationship between IGF-I and IGFBP-3 in individual infants, regardless of gestational age at birth, just as in childhood and adolescence (20). However, the developmental patterns of IGF-I and IGFBP-3 differed from each other and were further influenced by gestational age at birth. The exact role of IGFBP-3 in regulating the actions of IGF-I is not known, but IGFBP-3 is a part of the major IGF-I-binding protein complex. In normal children, it has been suggested ( 20 , 27) that the pubertal surge in IGF-I accompanied by a less prominent increase in IGFBP-3 could favor growth. A different situation seems to exist in constitutionally tall children and adolescents who demonstrate a higher than age-appropriate IGF-I concentration but lower than age-appropriate binding protein concentration (8). Because growth rate is higher during fetal life than in the postnatal period, a low or undetectable IGFBP-3 in the fetal tissue may have a permissive influence on the growth-promoting actions of IGF-I. Likewise, the lower IGFBP-3 reported here in male infants compared with female infants who had similar IGF-I may be related to the greater growth in male compared with female infants.

In summary, although a great deal more work will be required to understand how the relationship between IGF-I and its binding proteins influences growth, normative data on plasma IGF-I and IGFBP-3 in healthy, appropriately grown term infants are a necessary start. These normative data are contrasted here with concentrations found in healthy, normally growing preterm infants. The data demonstrate 1 ) that IGF-I and IGFBP-3 have different developmental patterns in the first year of life and 2) that each is influenced by gestational age at birth.

Acknowledgments. The authors thank Susan Werkman and Amy Ford for their support.

\section{REFERENCES}

1. Froesch ER, Schmid C, Schwander J, Zapf J 1985 Actions of insulin-like growth factors. Annu Rev Physiol 47:443-467

2. Cohick WS, Clemmons DR 1993 The insulin-like growth factors. Annu Rev Physiol 55:131-153

3. Baxter RC, Martin JL 1989 Binding proteins for the insulin-like growth factors: structure, regulation and function. Prog Growth Factor Res 1:49-68

4. Conover CA, Ronk M, Lombana F, Powell DR 1990 Structural and biological characterization of bovine insulin-like growth factor binding protein-3. Endocrinology 127:2795-2803
5. Elgin RG, Busby Jr, WH, Clemmons DR 1987 An insulin-like growth factor (IGF) binding protein enhances the biologic response to IGF-I. Proc Natl Acad Sci USA 84:3254-3258

6. Zapf J, Walter H, Froesch ER 1981 Radioimmunological determination of insulin-like growth factors I and II in normal subjects and in patients with growth disorders and extrapancreatic tumor hypoglycemia. J Clin Invest 68:1321-1330

7. Furlanetto RW, Underwood LE, Van Wyk JJ, D'Ercole AJ 1977 Estimation of somatomedin-C levels in normals and patients with pituitary disease by radioimmunoassay. J Clin Invest 60:648-657

8. Gourmelen M, Le Bouc Y, Girard F, Binoux M 1984 Serum levels of insulin-like growth factor (IGF) and IGF binding protein in constitutionally tall children and adolescents. J Clin Endocrinol Metab 59:1197-1203

9. Merimee TJ, Zapf J, Froesch ER 1981 Dwarfism in the pygmy. An isolated deficiency of insulin-like growth factor I. N Engl J Med 305:965-968

10. Laron Z, Pertzelan A, Mannheimer S 1966 Genetic pituitary dwarfism with high serum concentration of growth hormone-a new inborn error of metabolism? Isr J Med Sci 2:152-155

11. Thieriot-Prevost G, Boccara JF, Francoual C, Badoual J, Job JC 1988 Serum insulin-like growth factor $I$ and serum growth-promoting activity during the first postnatal year in infants with intrauterine growth retardation. Pediatr Res 24:380-383

12. Bala RM, Lopatka J, Leung A, McCoy E, McArthur RG 1981 Serum immunoreactive somatomedin levels in normal adults, pregnant women at term, children at various ages, and children with constitutionally delayed growth. J Clin Endocrinol Metab 52:508-512

13. Rosenfeld RG, Wilson DM, Lee PD, Hintz RL 1986 Insulin-like growth factors I and II in evaluation of growth retardation. J Pediatr 109:428-433

14. Hintz RL, Suskind R, Amatayakul K, Thanangkul O, Olson R 1978 Plasma somatomedin and growth hormone values in children with protein-calorie malnutrition. $\mathrm{J}$ Pediatr 92:153-156

15. Grant DB, Hambley J, Becker D, Pimstone BL 1973 Reduced sulphation factor in undernourished children. Arch Dis Child 48:596-600

16. Tato L, Du Caju MVL, Prévŏt C, Rappaport R 1975 Early variations of plasma somatomedin activity in the newborn. J Clin Endocrinol Metab 40:534-536

17. Kaplowitz PB, D'Ercole J, Van Wyk JJ, Underwood LE 1982 Plasma somatomedin $C$ during the first year of life. J Pediatr 100:932-934

18. Lineham JD, Smith RM, Dahlenburg GW, King RA, Haslam RR, Stuart MC, Faull L 1986 Circulating insulin-like growth factor I levels in newborn premature and full-term infants followed longitudinally. Early Hum Dev 13:37-46

19. Bernardini S, Spadoni GL, Povoa G, Boscherini B, Hall K 1992 Plasma levels of insulin-like growth factor binding protein-1, and growth hormone binding protein activity from birth to the third month of life. Acta Endocrinol 127:313-318

20. Blum WF, Albertsson-Wikland K, Rosberg S, Ranke MB 1993 Serum levels of insulin-like growth factor I (IGF-I) and IGF binding protein 3 reflect spontaneous growth hormone secretion. J Clin Endocrinol Metab 76:1610-1616

21. Breier BH, Gallaher BW, Gluckman PD 1991 Radioimmunoassay for insulin-like growth factor-I: solutions for some potential problems and pitfalls. J Endocrinol 128:347-357

22. Blum WF, Ranke MB, Kietzmann K, Gauggel E, Zeisel HJ, Bierich JR 1990 A specific radioimmunoassay for the growth hormone $(\mathrm{GH})$-dependent somatomedinbinding protein: its use for diagnosis of GH deficiency. J Clin Endocrinol Metab 70:1292-1298

23. SAS Institute, Inc. 1985 User's Guide: Statistics Version 5 Edition. SAS Institute, Cary, NC

24. Bennett A, Wilson DM, Liu F, Nagashima R, Rosenfeld RG, Hintz RL 1983 Levels of insulin-like growth factors I and II in human cord blood. J Clin Endocrinol Metab 57:609-612

25. Lassarre C, Hardouin S, Daffos F, Forestier F, Frankenne F, Binoux M 1991 Serum insulin-like growth factors and insulin-like growth factor binding proteins in the human fetus: relationships with growth in normal subjects and in subjects with intrauterine growth retardation. Pediatr Res 29:219-225

26. Teale JD, Mark SV 1986 The measurement of insulin-like growth factor I: Clinical applications and significance. Ann Clin Biochem 23:413-424

27. Argente J, Barrios V, Pozo J, Munoz MT, Hervas F, Stene M, Hernandez M 1993 Normative data for insulin-like growth factors (IGFs), IGF-binding proteins, and growth hormone-binding protein in a healthy Spanish pediatric population: age- and sex-related changes. J Clin Endocrinol Metab 77:1522-1528

28. D'Ercole AJ, Hill DJ, Strain AJ, Underwood LE 1986 Tissue and plasma somatomedin-C/insulin-like growth factor I concentrations in the human fetus during the first half of gestation. Pediatr Res 20:253-255

29. Saini JR, Morgan JB, Teale JD, Kovar IZ 1989 Insulin-like growth factor-I in the parenterally fed low birth weight infant. Ann Nutr Metab 33:88-91 